\title{
WSPU Rhetoric: \\ Justifying Militancy
}

No. 1, 5-15

(c) The Journal Editors 2017

Reprints and permissions: https://tidsskrift.dk/lev

DOI: $10.7146 /$ lev.v0i1.96777

Recommendation: Mark Eaton

(engme@cc.au.dk)

History, Society, and Culture 2

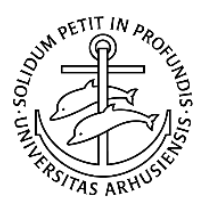

\section{Emilie Boutrup Högagarð}

\begin{abstract}
This article investigates the rhetoric employed by the Women's Social and Political Union (WSPU) in the UK during the campaign for women's suffrage. It argues that the rhetoric, as a result of adopting a militant approach, increasingly served the purpose of justifying the method rather than the cause. Based on an analysis of speeches by leading members of the WSPU, the article finds that the Union rhetoric justified the use of militancy by systematically drawing on democratic and social values, attacking the credibility of the legislators, promoting binary thinking and situating the conflict within the framework of a "just war."
\end{abstract}

Keywords: Women's Social and Political Union, WSPU, Pankhurst, women's suffrage, votes for women, militancy, rhetoric, just war, polarization, political rights, United Kingdom.

Corresponding author: Emilie Boutrup Högagarð (emilie.h.95@ hotmail.com)

Department of English, Aarhus University 


\section{Introduction}

Revolution and reform. The two are often confused, but they are significantly different from one another. Reformers seek modification within an existing system with the aim of stabilizing that system; revolutionaries seek to overthrow the system and establish a new one. But what happens when reformers, who are supposed to work towards the stability of society, adopt revolutionary methods? They are met with criticism and resistance, and a great justificatory burden. During the Edwardian campaign for women's suffrage, the Women's Social and Political Union (WSPU) would come to realize that their adoption of militant methods was a point of contention, not just outside but also within the organization, demanding a rhetorical strategy to accompany and justify it.

I argue that, while the WSPU sought to promote the cause of women's suffrage, their rhetoric, as a result of adopting the militant method, increasingly served the purpose of justifying the method rather than the cause. This paper demonstrates that the WSPU employed a rhetoric which was consistent both in themes and in techniques. Firstly, the rhetoric focused on democratic and social values such as justice, liberty and unity. Secondly, it demonstrated the lessons of history. Thirdly, it encouraged binary thinking by portraying the battle between suffragettes and the government as one between good and evil. Finally, it justified the use of violence by framing the suffrage campaign as a 'just war'. Due to the limited page range, this paper will refrain from analyzing the written propaganda, although this can provide material for further study, and restricts itself to the rhetoric used in the WSPU's speeches. The analysis of WSPU rhetoric will be based primarily on three speeches: Christabel Pankhurst's speech upon her prison release in 1908; Annie Kenney's speech on March 19, 1908; and Mrs. Emmeline Pankhurst's speech on October 17, 1912. In addition, two speeches by Mrs. Pankhurst, from 1908 and 1913 respectively, will be used to a very limited extent. Finally, the analysis of the WSPU's rhetorical justification of militancy in relation to the "just war" tradition, is inspired by the work of Cheryl R. Jorgensen-Earp.

\section{The Women's Social and Political Union}

The campaign for women's enfranchisement in Britain is traditionally divided into the Victorian and the Edwardian campaign. The agents of the Edwardian campaign can be further divided into suffragists and suffragettes. The suffragists, with the most prominent group being the National Union of Women's Suffrage Society (NUWSS), campaigned for women's suffrage through peaceful and constitutional means. The suffragettes used more militant tactics to achieve the same goal. This paper will focus on the most prominent suffragette group: the Women's Social and Political Union (WSPU) formed in 1903 by Mrs. Emmeline Pankhurst and her daughter Christabel. Henceforth, the term suffragettes will be used interchangeably with WSPU. Christabel was a member of the Independent Labour Party (ILP) and the NUWSS, but became increasingly impatient with the lack of progress and 
did not feel that working women could trust men, even Labour Party men, to protect their interests. When an ILP candidate failed to include women's suffrage in his election address, she stressed: "We want friends who will do something practical," setting the tone for what would later become a WSPU slogan 'Deeds not Words' (Rosen 28). Mrs. Pankhurst, also an ILP member, shared her daughter's view and decided that working women needed a new organization which would focus on fighting for their interests. Therefore, they formed the WSPU with the resolution to remain "absolutely free from any party affiliation" (My Own Story 38). While the WSPU was not officially affiliated with the ILP, Mrs. Pankhurst and Christabel remained members until 1907 when they were no longer dependent on the ILP for publicity, speaking platforms and financial support, thus making it possible to realize the 'no party affiliation' principle. The decision to "be independent of Labour men" led to disagreements within the organization and a call for democracy (Joanou and Purvis 159). When Mrs. Pankhurst instead selected a new committee and eliminated the parts of the constitution relating to organization, prominent members left the Union and formed the Women's Freedom League on the basis of organizational democracy. The WSPU carried on, now as an organization of "leaders and followers." While they considered universal suffrage to be the ultimate goal, their aim was for the existing franchise to be extended to women as they believed this to be a necessary first step (Rosen 94; 34). In retrospect it seems they were right; in 1918 women were granted limited suffrage while all men over 21 were enfranchised. It was not until 1928 that suffrage was extended to all women thus granting equal franchise to men and women.

In the early years of the WSPU, militancy was not on the agenda, as Christabel later wrote: “Our work was still entirely peaceful and educational" (Unshackled 44). The 'peaceful' work included: legal demonstrations, drafting of petitions, lobbying MPs and travelling the country to speak at various meetings. However, after a Woman Suffrage Bill, in which they had invested much time and energy, was rejected by the House of Commons, Christabel concluded that, "peaceful methods had failed" (Unshackled 47). Finding that a 'crisis' had made the Scottish Churches Dispute Bill a priority and that the Manchester 'riot' had secured the passing of the Unemployed Relief Bill, Christabel decided to adopt the confrontational approach. If a crisis was needed before the government acted, then the WSPU had to create such a crisis. Marking the beginning of WSPU militancy, Christabel and Annie Kenney went to a Liberal Party meeting and shouted: "Will the Liberal Government give votes to women?" They received no answer, but were dragged out and to ensure their imprisonment Christabel spat at one of the policemen. (Unshackled 50). As Christabel had expected, "militancy was news" and newspapers such as Manchester Guardian and The Times wrote about the WSPU and the trial of Christabel and Annie. The publicity resulted in large audiences for WSPU speakers and an increase in membership. It was clear that this was to be their basic strategy; a militant action followed by imprisonment, which led to media coverage, which resulted in membership increases and wider public support for the cause (Rosen 53). The WSPU suspended 
militancy in 1910 and 1911 while two conciliation bills were debated in parliament, however, when these were rejected WSPU militancy escalated into more violent and destructive methods including window breaking, arson, bomb attacks on private property, and destruction of telephone wires, golf courses and artwork.

\section{Rhetoric}

The objective of WSPU rhetoric was to promote militancy as the necessary course of action to secure women's suffrage. However, in order to do this they would first have to address the criticism and resistance they had received because of these methods. It would appear that Edwardian Britain was not ready for the reformist 'violent' woman that was the suffragette. The significance of this issue becomes very clear when one analyzes WSPU rhetoric and finds that most of it, directly or indirectly, is meant to justify the methods employed by the union. In the words of Jorgensen-Earp, the suffragettes faced the criticism "with a series of justificatory arguments remarkable for their thematic consistency" (27). Indeed, there are themes which appear time and again in WSPU speeches: justice, liberty, the government, the past, as well as the binary oppositions: guilty vs. innocent, villains vs. heroes, enemies vs. allies, and men vs. women. The structure of my analysis will not be divided into theses exact themes, for while they are all present in the speeches that are subject of my analysis, they overlap and so separating them stringently would affect the coherency.

\section{Democratic and Social Values}

When arguing in defense of women's suffrage, the WSPU emphasized democratic and social values such as justice, liberty and unity. In her speech in 1908, Christabel turns to the British constitution which states that "taxation and representation shall go together." She then draws the conclusion that "women tax payers are entitled to vote." The argument is designed to appeal to a feeling of injustice and a subsequent call for justice. She takes it one step further in the concluding section of her speech, when she makes the enfranchisement of women synonymous with "political justice" and creates a sense of urgency as she says: "We have waited too long for political justice; we refuse to wait any longer." This is one of the few examples of WSPU rhetoric seeking to justify the cause rather than the method. Generally they give it very little attention, suggesting that their main objective is to defend and promote the method needed to obtain the goal. Perhaps it also indicates a refusal to keep defending a cause which they believe has already been sufficiently justified by women for several decades. Indeed, Christabel also says that "the reasons why women should have the vote are obvious to every fair-minded person" (Christabel 1908).

The WSPU speakers create a sense of unity between themselves and the additional members in a number of ways. In the phrase "we women," which is repeatedly used in several WSPU speeches, 
the use of 'we' has a uniting effect while the repeated emphasis on the fact that they are women has an empowering effect depicting them as women of action, agency and determination: "we women are roused [...] we will never be quiet again" (Emmeline 1908). Christabel, after commenting on the government's refusal to honor democratic principles in regards to women, promotes the value of unity as she says: "They must be compelled by a united and determined women's enfranchisement measure" (Christabel 1908). Annie Kenney does more than unite suffragettes with one another, as she establishes a connection with reformers of the past whose strife "won for us the liberties we now enjoy" and links the WSPU with the future by assuming that "the strife of today will win liberty and freedom for the generations that are to come." Kenney also refers to the WSPU as a "grand fellowship existing between women of every class, of every creed" (Kenney). In conclusion, unity exists between suffragettes, but also spans across time, reaches outside the boundaries of the Union and breaks the social construct of class.

\section{History}

The WSPU uses the past to illustrate the failure of the constitutional approach and the success of the militant approach. Christabel draws on the history of the Women's Suffrage Movement to defend the militant approach. Firstly, she portrays women as patient and innocent by referring to the constitutional methods that women have used "for forty years" trying to present their case in a "quiet and patient manner." Secondly, she places blame with the government by claiming that the constitutional approach did not work because "women have not been able to bring pressure to bear on the government and government moves only in response to pressure." She praises women's " "virtue' of patience" but by emphasizing that pressuring the government is necessary to generate change she effectively turns this 'virtue' into "the 'vice' of passivity" (Jorgensen-Earp 32). One might say that she is compelling women to accept militancy, given that they have no other choice, as a 'virtue of action' against a repressive government. Furthermore, Christabel emphasizes that men got the vote "not by persuading but by alarming the legislators." This juxtaposition between persuasion and alarm emphasizes the difference between the constitutional and the militant approach. Thus, history serves as evidence for her claim that militancy is necessary to secure enfranchisement. She creates a sense of necessity by repeatedly using the modal verb "must" combined with the passive voice: "Similar vigorous measures must be adopted by women. The excesses of men must be avoided yet great determination must be shown." She is clarifying that women will adopt the militant "measures" because they "must", but by saying that they will not go as far as men, she is also alluding to a female moral superiority of restraint (Christabel 1908). 


\section{Polarization and Rhetorical Binaries}

The WSPU speakers use a polarizing rhetoric, creating rhetorical binaries between those for and those against the cause. The binaries occur in many forms but the unifying factor is that they pertain to the idea of 'good versus evil' and of 'us versus them.' This simplified rendition of things promotes a sense of being united against a common enemy; the government.

\section{Heroes and Villains}

In her speech in 1908, Annie Kenney uses an allusion to create a binary between the suffragettes heckling a politician and the government: "We women were like the Barons in the Saga of King John." The traditional view is that King John was an autocratic king who abused his powers and the barons made him sign the charter which would protect the English people against his vices. By comparing the suffragettes to the barons, she is declaring them heroes. The villain corresponding to King John is the government, "run on unconstitutional lines." The suffragettes are fighting for a cause which is as righteous as the fight against absolutist monarchs; they are fighting for individual freedom and political rights (Kenney).

Furthermore, she undermines the credibility of the government by emphasizing problematic conditions in society. She challenges the audience to look at the conditions people are living under and "be satisfied with life as it is if you can!" She paints a vivid picture of the conditions of the sick, the poor, the old and the children and points to the symptoms of a faulty system: overcrowded prisons, workhouses and asylums. What she is implying is that these are man-made conditions, and that suffragettes, as women, are concerned with protecting the weak and therefore cannot be satisfied with the way things are. In fact she says that "it would be wrong if we women were satisfied [...] if we women did not burn with righteous indignation." She portrays suffragettes as having a high sense of morality, but also as being angry because they can see injustices which the legislators are not making a priority. If these women are the only ones who care about changing the conditions of these people, then the government, by denying votes for women, is also denying these people better conditions. Thus the suffragettes emerge as selfless heroines and the government as the selfish villain. By claiming that women have the ability to improve the social conditions of the lower members of society and by emphasizing women's eagerness to do so, she is also advocating for the cause, not just the method (Kenney).

Christabel establishes a positive image of women engaged in militancy as she emphasizes that it is, "clearly thought out and vigorously pursued." Furthermore, she takes away any shame connected with imprisonment as she declares it the result of "repressive legislation". She thus emphasizes their innocence and places blame with the Government. She does not, however, allow women to remain in the role of the victim, for she believes that "women must banish the idea that "weakness is 
womanliness. Women must be self-reliant and strong"' (as quoted in Joanou and Purvis 158) ${ }^{1}$. Instead she concludes by saying that imprisonment "will not deter women from asking to vote," thus empowering women and encouraging them to pursue militancy even if it leads to imprisonment (Christabel 1908).

\section{Allies or Enemies}

Since the split in 1907 the Pankhursts had not accepted any criticism within the WSPU, they expected complete obedience. After the massive window-breaking campaign of 1912 and hearing of the plans for an arson-campaign, Mr. and Mrs. Pethick-Lawrence (founders of the Union's magazine Votes for Women) started questioning the increasingly violent methods of the WSPU. As a result, they were expelled. Giving a speech shortly after on October 19 1912, Mrs. Pankhurst opens with "it is better that those who cannot agree [...] should set themselves free." She praises their years of service, convinced that it is best for everyone that they each work in their own way. While it is clear that there has been some disagreement, she avoids specifying whether they were expelled or chose to leave and thus manages to come off in a positive light. However, one cannot help but wonder if her next statement is directed at them or perhaps a warning to other members, not to follow their example: "So long as you keep in office an anti-suffrage Government, you are parties to their guilt, and [...] we offer you the same opposition [as we give them]" (Emmeline 1912). This is an example of polarizing rhetoric as it furthers an us versus them attitude. It has an exclusionary effect; it limits allies to those who completely agree with Mrs. Pankhurst, and it makes an enemy of anyone who disagrees. The possibility for bystanders to be moderate or neutral on a certain aspect is removed and they are forced to choose sides. It is not uncommon in political communication, and while it is not as explicit, its essence is the same as George Bush's famous declaration: "Either you're with us, or against us" (Stocchetti 234).

\section{The Oppressor and the Oppressed}

When claiming that there is "a great deal of criticism" of the movement and militancy in women from “anti-suffrage members of the Government," Mrs. Pankhurst uses a predator-prey simile: "it is very like beasts of prey reproaching the gentler animals who turn in desperate resistance when at the point of death." The anti-suffrage members are made out to be predators and the suffragettes as the "gentler animals," the prey. The logic is that in a 'survival of the fittest' scenario, the predator hardly has the right to blame the innocent prey for whatever attempts it makes to defend itself. Mrs. Pankhurst effectively reverses the order; the suffragettes are not attackers, they are being attacked. Consequently

${ }^{1}$ Originally from Sunday Times, 8 March 1908. 
their militancy is an expression not of aggression but of self-defense turned to as a last resort against oppression (Emmeline 1912).

\section{Militancy}

The later speeches of the WSPU reflect the increase in violent militancy in the late years of their campaign as the rhetoric is much more explicit regarding militancy compared to the speeches of the earlier years. For example, delivering a speech in March 1908, Mrs. Pankhurst's only reference to militancy is when she advises "every one of you to do your part" and adds "you need not go to prison" (Emmeline 1908). Christabel is a little more explicit in her speech, also given in 1908, providing two examples of militancy: "protesting at public meetings" and "marching to the House of Commons in procession" (Christabel 1908). With stone-throwing and hunger strike not being initiated before 1909, Christabel has essentially (while not exhaustively) accounted for WSPU militancy. While I refer to it as militancy, it seems relevant, while dealing with the development of militancy, to point out that this early form of militancy was disruptive rather than destructive in nature. Indeed, as Mrs. Pankhurst, in 1913, looks back at the early years when the term 'militant' was first applied to suffragettes she says: "It was not militant at all" (Emmeline 1913). By 1912, however, WSPU militancy was destructive in nature and Mrs. Pankhurst is very explicit about ways of being militant and very direct in recommending the approach. She places extra emphasis on this section of the speech by using a complex form of repetition (symploce) which combines the anaphora "Those of you who can express militancy" and the epistrophe "do so." She repeats the pattern five times, but alters the pattern in the final two clauses of the section suggesting further intensification. For example, in the sentence "those of you who can break windows - break them," replacing the epistrophe with "break them" has an emphatic effect. Indeed, this section is cleverly constructed considering her aspiration to "incite this meeting to rebellion" (Emmeline 1912).

\section{A "Just War"}

With the implementation and escalation of militancy came an increasing need, for the WSPU leadership, to defend their methods. This became the main purpose of their speeches and articles; to justify and promote the use of militancy to achieve women's suffrage. Not only did they have to justify it to the government (who could grant them a reform) and the general public (which could pressure the government,) they also had to defend it to the WSPU members, who had to carry out the militant acts. There was also the issue of what Cheryl R. Jorgensen-Earp calls "a double justificatory burden." The suffragettes had to defend their views and tactics not only as reformers but also as women (9). It might seem redundant, even politically incorrect today, but it should not be a major surprise that women, in a time where Victorian ideals still lingered, had a greater responsibility of 
justifying the use of violence. While the WSPU leaders do not explicitly speak in terms of war, until the later years, they prove the injustices that force them to act, and they prove the necessity of the use of militancy. This constitutes as evidence to the claim made by Jorgensen-Earp that the WSPU framed violence as part of a just war. The 'just war' doctrine was developed by Christian theologians in the Middle Ages to address the moral/ethical issues connected with war and violence in a Christian society. It states that a war is justifiable only if the reasons for going to war can be justified and the proper conduct in war is exhibited (the means must be justifiable). The 'just war' was a "common conservative tradition they shared with British men for explanation and justification for their acts" (Jorgensen-Earp 10). Thus, by extending the rationale of the 'just war' tradition to women the suffragettes "highlighted the hypocrisy of those who claimed that the suffragettes had gone too far in their pursuit of justice" (153). The suffragettes did not invent a new tradition, but they refused to accept that such a tradition, which allowed men to use violence for a just cause, should not be equally applicable to them. Regardless of whether the WSPU had the 'just war' concept in mind, it is certainly clear that they focused on some of the same issues that are raised in the 'just war' tradition. They sought to prove that suffragettes turned to violence only after all other options had been exhausted; that the violence was thought-out and carefully carried out with regard for human life; that the good to be gained (liberty for half the population) from the violence outweighed the evil inherent in the violence (destruction of property).

While the 'just war' -appeal was mostly implicit in the earlier campaign years, by 1912 it has become highly explicit, suggesting that the need for justification, through "the logic of warfare", is growing simultaneously with the increasingly violent methods employed (Taylor 58). The use of words normally associated with warfare is indicative of the radicalization of WSPU militancy. Its intention is for the audience to look at suffragette militancy not through the framework of the 'democratic society' but through the framework of a 'just war'. As long as the audience accepts this framework, it provides a justification for the use of violence and even allows the suffragettes to portray their violence as highly limited, controlled and merciful compared to the violence used in the warfare of men. For example, as Mrs. Pankhurst says in her speech in 1912, the suffragettes do not “endanger human life. We leave that to the enemy. We leave that to the men in their warfare." Having thus portrayed suffragette methods as morally superior to those of men, she moves to proving that such a moral superiority also exists in regards to the values they protect, as she states that the suffragettes fight for the "liberty," "dignity" and "welfare of women," whereas the government cares more about "the security of property." She declares: "we shall continue this war" and offers a rationale for the material nature of WSPU militancy as she encourages followers to "still further attack the secret idol of property" (Emmeline 1912). 


\section{Conclusion}

The WSPU campaigned for women's suffrage, yet they did not focus much of their rhetoric on explaining why women should be allowed to vote. After decades of rejections, postponements and unfulfilled promises from the legislators, the WSPU had had enough of defending the belief that women should have the same political rights as men. They moved from defense to offense both in deeds and words. They adopted a militant method accompanied by a rhetoric which attacked the legislators by portraying them as materialistic oppressive hypocrites who only sought to maintain their own interests and failed to honor the principles of the constitution; the very basis of democracy. They justified their methods by proving that it was the only method that would accomplish the goal and emphasizing that the WSPU only used these methods as a last resort; aware that they were beneath women, but forced to employ them as it was the only thing the immoral government responded to. As militancy increased so did reservations relating to it and in response, the WSPU reinforced the polarizing rhetoric making it clear that there was no room for indecisiveness or cowardice in war. Listeners had to choose sides, and the choice was made simple for them; are you a hero or a villain, innocent or guilty, good or evil, with us or against us? 


\section{References}

Joanou, Maroula and June Purvis, editors. The Women's Suffrage Movement: New Feminist Perspectives. Manchester University Press, 1998.

Jorgensen-Earp, Cheryl R. The Transfiguring Sword: The Just War of the Women's Social and Political Union. The University of Alabama Press, 2015. Google Books, books.google.dk/books?id=CzLJBwAAQBAJ\&printsec=frontcover\&hl=da\&source=gbs_atb\#v= onepage \&q\&f=false , accessed 30 May 2017.

Kenney, Annie, speaker. "Speeches by Members of the Women's Social and Political Union." Royal Albert Hall Meeting, 19 March 1908. Transcript of speech. The National Archieves, discovery.nationalarchives.gov.uk/details/r/143bc05f-3e63-4603-9be7-8daf75a7c881, accessed 30 May 2017.

Pankhurst, Christabel. 1908. "Source 16 - Christabel Pankhurst [Transcript of speech given upon her release from prison]". British Library, www.bl.uk/learning/histcitizen/21cc/struggle/suffrage/sources/source16/christabel.html, accessed 30 May 2017.

Pankhurst, Christabel. Unshackled: The Story of How We Won the Vote. Edited by Lord PethickLawrence of Peaslake, Hutchinson \& Co., 1959.

Pankhurst, Emmeline, speaker. "Freedom or Death.” Hartford, Connecticut, 13 November 1913. Transcript of speech. The Guardian, www.theguardian.com/theguardian/2007/apr/27/greatspeeches, accessed 30 May 2017.

---, speaker. "I Incite This Meeting to Rebellion.” Royal Albert Hall Meeting, 17 October 1912. Transcript of speech. History is a Weapon, www.historyisaweapon.com/defcon1/pankhurstincitetorebel.html, accessed 30 May 2017.

---, My Own Story. London, Eveleigh Nash, 1914 Gutenberg, www.gutenberg.org/files/34856/34856-h/34856-h.htm, accessed 30 May 2017.

---, speaker. "Speeches by Members of the Women's Social and Political Union." Royal Albert Hall Meeting, 19 March 1908. Transcript of speech. The National Archieves, discovery.nationalarchives.gov.uk/details/r/143bc05f-3e63-4603-9be7-8daf75a7c881, accessed 30 May 2017.

Rosen, Andrew. Rise Up, Women: The Militant Campaign of the Women's Social and Political Union 1903-1914. Vol. 23, Routledge, 2014.

Stocchetti, Matteo. "The Politics of fear: a Critical Inquiry into the Role of Violence in $21{ }^{\text {st }}$ Century Politics." Discourse, War, Terrorism, edited by Adam Hodges and Chad Nilep.

Discourse Approaches to Politics, Society and Culture, vol. 24, John Benjamin Publishing Company, 2007, pp. 223-241.

Taylor, Maxwell. The Terrorist. London, Brassey's Defence Publishers, 1988. 